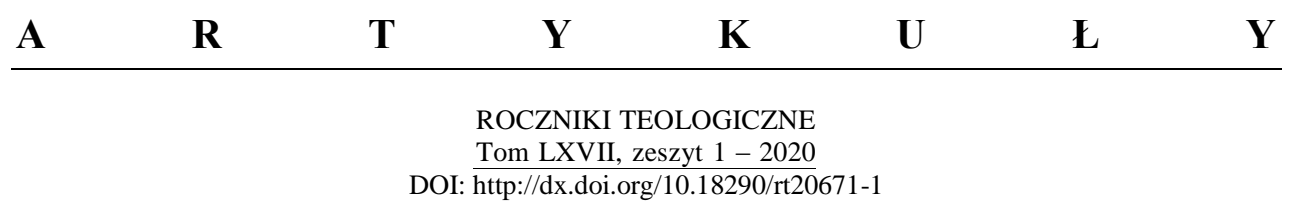

MYKOLA BULATEVYCH

\title{
THE PROBLEM OF THE STATUS OF GLOBAL CIVIL SOCIETY IN THE WORKS OF CERTAIN REPRESENTATIVES OF EUROPEAN CRITICAL THEORY
}

\begin{abstract}
This article deals with the problem of defining the status of global civil society as this problem is set in the works of certain representatives of European critical theory, in particular, Nancy Fraser, Ulrich Beck and Jürgen Habermas. The notion of national civil society was described, and the key elements indispensable for the establishment and functioning of national civil society have been identified. Based on works of the aforementioned representatives of European critical theory, it was shown that certain key elements are still missing before we can talk about a fully sophisticated global civil society. The ways of solving the problem of the status of global civil society proposed by the aforementioned representatives of European critical theory have been outlined.
\end{abstract}

Key words: global capitalist economy; world civil community; global public sphere; supranational state formation; global public opinion.

\section{RELEVANCE OF STUDIES}

The subject of global civil society was drawing attention of philosophers and scholars specializing in social sciences at least from the late $18^{\text {th }}-$ early $19^{\text {th }}$ century. One of the examples worth mentioning is Henri de SaintSimon's concept of global association organized on socialistic principles of a single global community with which the entire mankind would have to subsequently "merge". Another example is Immanuel Kant's teaching about the world civil order founded on the basis of a rational system of laws,

Myкola Bulatevych, Ph.D. of Sociology, Associate Professor of the Department of Sociology and Public Communications, National Pedagogical Dragomanov University; address for correspondence: 02000 Kyiv, Ukraine, Pyrogova street 9; e-mail: n.bulatevich@ukr.net 
reaching which is the ultimate goal of the mankind's historical development. Later on, this subject was actively developed in social sciences, although in certain periods, the contemporaneity of this subject could somewhat decline due to certain historical circumstances.

A new wave of growing interest in the subject of global civil society began in the 1980s and continues till present time. During this period, interest of scholars in analyzing the structures and processes reaching beyond the boundaries of national societies was on the rise. Social science scholars are developing a number of areas of studying global civil society, regarding it as a quite completed autonomous entity. But at the same time, certain scholars point out that this autonomous status of global civil society is not obvious and requires substantiation. Not everything is quite clear with it. In this context, the key aspect is the need to answer the question whether global civil society is, in the words of Viktor Stepanenko, indeed an entity that really exists and represents an effective democratic alternative to non-liberal globalization of the economy and politics, or it is rather a decorative feature or a sort of a valve to "vent the steam" of discontent with global social injustice. ${ }^{1}$

The problem of the status of global civil society is an important subject for certain representatives of European critical theory as well, in particular, in the context of developing the so-called "project of incomplete modern." The works by, for instance, Nancy Fraser, Ulrich Beck and Jürgen Habermas vividly highlight the main problematic aspects that concern this matter. These representatives of European critical theory point out that for the time being, the problem of identification or substantiation of the autonomous status of global civil society remains unresolved and requires further elaboration and solution. By generalizing their arguments, we can outline more specifically the very problem and indicate its key aspects.

Therefore, the purpose of this article is to outline, in general terms, the problem of the status of global civil society in the works of certain representatives of European critical theory. The study presented in this article is based on the works by Nancy Fraser, Ulrich Beck and Jürgen Habermas, because these works address this problem in a vivid and telling manner and set out the key arguments related to it.

\footnotetext{
${ }^{1}$ Hlobalizatsiia v sotsiolohichnomu vymiri, Pid redaktsiieiu V. Stepanenka ta V. Burlachuka (Kyiv: Instytut sotsiolohii NAN Ukrainy), 168; J. GoRBANIUK, "Cultural Globalization and its Consequences on Marital-Family Life," in J. Gorbaniuk (ed.), The Situation of the Family in Contemporary Society - Experiences of Middle-Eastern Europe (Lublin: Publishing House of KUL, 2007), 7-15.
} 


\section{RESULTS AND THEIR ANALYSIS}

Representatives of European critical theory consider civil society within the confines of a territorially limited social unit termed as "modern society." Civil society constitutes a structural element of this unit, distinct from its other two basic structural elements, capitalist economy and the modern state. Each of the three is interpreted as an autonomous sphere developing according to its own inner logic. Capitalist economy is considered as a sphere within framework of which purposive-rational economic relations are ordered to create and distribute surplus value. The state represents a sphere in which purposive-rational relations concerning distribution and exercising of administrative powers are unfolded. Civil society is a domain of communicative relations. An open rational communication that has the purpose of achieving the mutual understanding or consensus about how to organize common, collective life based on universal principles of justice takes place in this domain. Within "modern society" economy, the state and civil society, on the one hand, confront each other, but on the other hand, they supplement each other in their functions, thus stabilizing each other. ${ }^{2}$

Based on Nancy Fraser's work, we can distinguish the following features of civil society: it territorially coincides with legally defined boundaries of a certain modern society; as a result of communication, it produces public opinion addressed to the state that exercises sovereignty over this territory; the subjects of communication are members of a legally constituted political community - nation, i.e. citizens of the state who can join voluntary nongovernmental and noncommercial associations, organizations and movements; every citizen has the same right to participate in communicative processes as other citizens; communication is implemented via national mass media, which connect territorially scattered participants with each other; communication requires the existence of a common linguistic medium: official language or several official languages. ${ }^{3}$

Civil society functions in a way that attracts attention to actions, events, states of affairs, etc. that, occurring in particular spheres of modern society, cause injustice. Citizens of the state "become outraged" and enter communicative networks of the public sphere to comprehensively discuss these

\footnotetext{
${ }^{2}$ J. HABERMAS, The theory of communicative action. Volume one: reason and the rationalization of society. Translated from German by Thomas McCarthy (Boston: Beacon Press, 1984), 217-219; J. HABERMAS, The theory of communicative action. Volume two: lifeworld and system. Translated from German by Thomas McCarthy (Boston: Beacon Press, 1987), 318-319.

${ }^{3}$ Transnationalizing the Public Sphere, ed. Kate Nash (Cambridge: Polity Press, 2014), 10-12.
} 
actions, events and states of affairs in order to reach a consensus on the attitude to be displayed toward them and find the ways to fix the situation. As a result, civil society generates public opinion and uses it to put pressure upon administrative apparatus of the state and force the latter to adopt and carry out decisions aimed to restore justice. By participating in communicative processes of producing public opinion, citizens of the state become convinced that they have real influence upon organization of social relations in particular social domains. Society becomes for them their own "lifeworld" that they constitute for themselves, and the feeling of belonging to the same national community becomes stronger among them, thus strengthening social solidarity.

Jürgen Habermas shows that in the historical perspective, modern society as a special type of social system has appeared in countries of the geographical region called Western Europe in the early modern period. Its advent was caused by the birth and development of capitalism in this region. However, in the early modern period modern society did not reach a sufficient degree of rationalization yet. Its three basic structural elements have already become distinguishable, but the process of their separation from each other was still incomplete. In particular, civil society has not become fully separated from the capitalist economy. The latter two elements were a part of a single broad public sphere. This sphere encompassed voluntary private and public organizations and associations outside state borders, as well as the capitalist market with its institutions. It confronted the absolutist state, and the small, balanced commercial economy limited by territorial boundaries and functioning on the basis of private property in the conditions of open market served as its base. ${ }^{4}$

Rationalization of modern society has completed during the late modern period which started after the French Revolution. The absolutist state gives way to a formally more democratic state. Finally, the capitalist economy and civil society become fully separated from each other, shaping up as autonomous realms. Along with the sphere of state, all three of them together form the systemic frame of modern society. But now, the problem of systemic balance between them takes center stage. In the societies of certain countries, there could be a situation when either the state or the capitalist economy rises above the other two spheres, invades their boundaries and subordinates them to the logic of its development, thus disrupting their normal functioning.

\footnotetext{
${ }^{4}$ J. HABERMAS, Between facts and norms: Contribution to a discourse theory of law and democracy. Translated from German by William Rehg (Cambridge: The MIT Press, 1998), 44.
} 
Both the first and the second scenarios have been described in the works by representatives of European critical theory, from György Lukács to Jürgen Habermas.

When state towers above capitalist economy and civil society, a nondemocratic (e.g. authoritarian or totalitarian) political regime establishes in a country. Under such circumstances civil rights and obligations are cut off, and a number of administrative repressive measures towards people increases. Private sector-driven market economy begins to degenerate, and the functioning of civil society is defined and controlled by the state, which is manifested, in particular, in the control by the state of the topics for communication and of the arguments that should be used in that communication.

When economy towers above the other base spheres and subordinates them to the logic of its development, the country sees the establishment of the so-called "wild capitalism." The state is reduced to the minimum, performing only the limited functions of a "nightwatch." The measure of exploitation and impoverishment of lower classes is increased. Communication in the civil society domain becomes fragmentary and reified under the pressure from an uncontrolled and unregulated market, and the mechanisms for communicative producing of public opinion fall apart. In both cases of insufficient differentiation - when either the state or economy dominates over the other two spheres - civil society cannot be considered sophisticated. Free rational communication in it degrades, the possibility of achieving mutual understanding in a communicative way becomes more difficult, and social solidarity weakens.

As a result of lengthy and complex transformations, Western societies were able to balance the three basic spheres after World War II. The final establishment of democratic or social-democratic political regimes limited authoritarian attempts of the state and enhanced the role of civil society. A democratic state was becoming accountable to it on legislative grounds. It had to heed the opinion of the nation of citizens, and decisions it made could not contradict this opinion. At the same time, the autonomous status of both civil society and the capitalist economy was legally formalized. On the other hand, using the mechanism of communicative production of public opinion and the subsequent pressuring of the state by the weight of public opinion demanding administrative measures, the society was able to rein in the capitalist economy, smoothen social injustice caused by its development, and as a result, establish such a method of economic management which Peter 
Koslowski called "ethical and democratic capitalism." Developed, rationalized, socially integrated modern societies came of age in Western countries.

The processes related to globalization of the capitalist economy upset the seemingly achieved systemic balance. Ulrich Beck maintains that starting from approximately the 1970s, capital has been transcending the boundaries of modern societies more and more actively, being deployed within the global space. A single global capitalist economy is being formed, going beyond national borders. It gains advantage over the state and civil society, because the latter two remain territorially rooted while the former is no longer tied to a particular territory. The global capitalist economy becomes able to relieve itself of the control by a democratic state and civil society on the one hand, and to weaken them and gradually subject them to the logic of its development, on the other. ${ }^{6}$

The new thrust of systemic imbalance produces adverse social consequences. Ulrich Beck states that domination of the global capitalist economy causes the growth of unemployment and underemployment, financial instability and financial crises, reduction of financing of social programs and social expenditures from the budget, and growing inequality and poverty. Moreover, unregulated development of the global capitalist economy disrupts the ecosystem of our planet, which may lead to global environmental disasters. ${ }^{7}$ Jürgen Habermas supplements the above list with such indirect consequences as the growing intolerance of foreigners, people with a different skin color or religious beliefs, etc., and the rise of right-wing populism even in successful democratic countries. These trends are accompanied by social disintegration and the growing effects of anomie. ${ }^{8}$

A modern society was able to make the capitalist economy regulated thanks to the efforts of the "union" of a democratic state and civil society. Since the capitalist economy transcends territorial borders of particular countries and becomes global, in order to make its functioning orderly, restore systemic balance and fix the socially unjust consequences it caused,

\footnotetext{
${ }^{5}$ P. KozLovsKi, Proschanie s marksizmom-leninizmom: o logike perehoda ot razvitogo sotsializma $k$ eticheskomu i demokraticheskomu kapitalizmu. Ocherki personalistskoy filosofii. Perevod s nemetskogo, pod redaktsiey M. N. Gretskogo (SPb: Ekonomicheskaya shkola, 1997).

${ }^{6} \mathrm{U}$. BEK, Vlast $i$ ee opponentyi $v$ epohu globalizma. Novaya vsemirno-politicheskaya ekonomiya. Perevod s nemetskogo A.B. Grigoreva i V.D. Sedelnika (Moskva: Progress-Traditsiya, Izdatelskiy dom «Territoriya buduschego», 2007), 22-25.

${ }^{7}$ Ibidem, 125.

${ }^{8}$ Yu Habermas, Politicheskie rabotyi. Perevod s nemetskogo B.M. Denezhkina (Moskva: Praksis, 2005), 288.
} 
representatives of European critical theory believe that both "members" of the aforementioned "union" also must enter the global public sphere. But are there any reasons to believe that the state and civil society have reached or are, so to speak, in the "process of reaching" the global level? At this point, European critical theory runs into difficulties. One could probably talk about the state reaching that level, considering the growth of, say, such a regional supranational political entity as the European Union, even though it is not characterized by important features of the state: monopoly on violence and monopoly on determining foreign policy.

But the situation with globalization of civil society looks more problematic. Communication networks of the public sphere went beyond the boundaries of particular societies, forming a single global communication space and allegedly enabling the establishment of global civil communication. There is also a number of global nongovernmental and noncommercial civic organizations whose areas of concern are not confined within the borders of one particular country. However, that's not enough. In order to be definitely sure about the existence of global civil society from the standpoint of European critical theory, two key indicators must be in place: a single world civil community whose members could legitimately participate in communicative processes of producing global public opinion, and a global political entity capable of regulating relations in the global public sphere and upon which the world civil community could legitimately put pressure. However, it still remains unclear whether these two indicators do exist.

Representatives of European critical theory are trying to identify them. However, this task isn't that easy. Various options are being proposed. Nancy Fraser talks about the existence of not one global but of several supranational civil communities functioning in parallel with each other. The criterion that serves as the basis on which representatives of various nations are grouping into a supranational community is their belonging to the same complex of global structures and institutes that define their everyday life. Since there are several complexes of global structures and institutes, the relevant supranational community is being created for each of them. A certain number of these communities are thus being formed, each generating its own supranational public opinion. These public opinions can put pressure upon supranational political entities, which are characterized by administrative power sufficient to regulate social relations at supranational level. A good 
example is the European Union. Nancy Fraser stresses that these supranational political entities require further development and enlargement. ${ }^{9}$

Ulrich Beck believes that environmental risks provide the basis for formation of a world civil community. Facing the threat of a global environmental catastrophe, all people regardless of their social class, status, race, religious beliefs, national identity, etc. will unite into a single global community for which salvation of the environment becomes the sense of existence. Ulrich Beck calls it a "world risk society." Communication networks of the global public sphere become the place where members of this society realize communication practices aimed at thematization, discussion and search of the ways of solving problems stemming from environmental threats. Given the absence of a single global political entity, global public opinion produced within the risk society puts pressure directly upon participants of the global capitalist economy to force their responsible attitude toward preservation of the environment. The pressure is exerted indirectly, via the ability of global public opinion to mobilize a global consumer movement whose participants may conscientiously refuse to buy products or services from a transnational manufacturer/provider that produces environmental risks. ${ }^{10}$

Jürgen Habermas talks about the need to adopt a world constitution that would have priority over national laws. The states would implement it without losing their sovereignty, because their constitutions would continue to remain in effect simultaneously with the world constitution. Firstly, this step would allow to legally create a single world civil community that would be characterized by a clearly defined legal status. Its representatives would become entitled to participate in the processes of producing global public opinion by communicating with each other via communication networks of the global public sphere. Members of this community would not lose their national identity but would simply attain an additional post-national identity. ${ }^{11}$

Secondly, the adoption of a world constitution would pave the way toward development of a single global political entity. It could have legitimate grounds to regulate social relations within the global space. It would not have the monopoly on violence, which would still be controlled by the governments of nation states. However, the latter would not be able to use physical force at their own discretion; instead, they could do it only in strict ac-

\footnotetext{
${ }^{9}$ Transnationalizing the Public Sphere, ed. Kate Nash (Cambridge: Polity Press, 2014), 30-33.

${ }^{10}$ U. BECK, World at Risk. Translated from German by Ciaran Cronin (Cambridge: Polity Press, 2011), 9-12, 97.

${ }^{11}$ J. HABERmAS, "Plea for a constitutionalization of international law," Philosophy \& Social Criticism (2014), 40(1): 7-8.
} 
cordance with the world constitution and only after political decisions made by the global state. Habermas names the basic aspects falling within the scope of competence of a global political entity: regulation of the global economy and, in particular, global financial markets, observance of human rights, preservation of the environment, maintaining peace, etc. ${ }^{12}$

A world parliament must become, in Habermas's opinion, the "legislative" body of a global political entity. This parliament should discuss contemporary global problems and challenges and make political decisions addressing them. There must be a continuous feedback between the world parliament and the world civil community. The feedback must be maintained, firstly, on the basis of a worldwide election procedure, and secondly, by generating global public opinion. Using it, members of the world civil community would be able to put pressure upon the world parliament and demand adoption of resolutions required at the particular moment. ${ }^{13}$ Habermas sees a reformed United Nations Security Council as the "executive" body of a global political entity. The Council would carry out resolutions adopted by the world parliament and, if necessary, may use physical force still controlled by nation states. Physical force would be used in accordance with the world constitution. In the scholar's opinion, it could take the form of lawful interventions, for example, where human rights are abused. ${ }^{14}$

Still, the arguments offered by representatives of European critical theory do not completely solve the problem. The indicators pointing out that interlocutors scattered across the globe constitute a single socially integrated civil community and are not accidental disintegrated participants, or that their communicative efforts would produce practical consequences from the viewpoint of regulating social relations within the global social space have not been completely and unambiguously established. European critical theory cannot unambiguously identify them. Instead, it rather points out that civil society must go beyond the boundaries of particular modern societies and must become global in order to balance, in the union with a global state which also still needs to be created, the functioning of the global capitalist economy.

\footnotetext{
${ }^{12}$ J. HABERMAS, The crisis of the European Union: a response. Translated from German by Ciaran Cronin (Cambridge: Polity Press, 2012), 58-61.

${ }^{13}$ Ibidem, 61-63.

${ }^{14}$ Ibidem, 61.
} 


\section{CONCLUSION}

According to representatives of European critical theory, there are two key elements that must be created to develop a national civil society: a communicative community - nation - legally defined on the basis of constitution, and a popular democratic state that would realize the will of that community. The problem of the status of global civil society is that on the one hand, communication networks of the public sphere went beyond the national boundaries of particular societies, have created conditions for global civil communication and give reasons to talk about a global civil society, but on the other hand, two key indicators are lacking for it to finally come of age: a legally defined world civil community and a global political entity upon which this community could put pressure by producing global public opinion.

Based on theoretical findings of representatives of European critical theory, we can conclude that until the existence of a single world civil community is unambiguously established and until a full-fledged, at least supranational political entity is developed, it would be somewhat premature to say that global civil society has become a completed, developed entity, despite the existence of sophisticated communication networks in the global public sphere and of global civic organizations.

Besides setting the problem of the status of global civil society, representatives of European critical theory also propose possible ways of solving this problem. However, their proposals are rather "constructivist." While the capitalist economy is globalizing in accordance with objective logic of its development, civil society by itself does not, for some reasons, go beyond the boundaries of national societies that simply. It must be prompted to do that; it must be helped by conscious efforts of citizens of various countries. This process is yet to take place; it has not been completed, and it requires further development.

\section{REFERENCES}

BeCK, U. World at Risk. Translated from German by Ciaran Cronin. Cambridge: Polity Press, 2011.

БЕк, У. Власть и ее оппоненты в эпоху глобализма. Новая всемирно-политическая экономия. Перевод с немецкого А.Б. Григорьева и В.Д. Седельника. Москва: Прогресс-Традиция, Издательский дом «Территория будущего», 2007 [ВЕК U. Vlast i ee opponentyi v epohu globalizma. Novaya vsemirno-politicheskaya ekonomiya. Perevod s nemetskogo A.B. Grigoreva i V.D. Sedelnika. Moskva: Progress-Traditsiya, Izdatelskiy dom «Territoriya buduschego», 2007]. 
Habermas, J. Between facts and norms: Contribution to a discourse theory of law and democracy. Translated from German by William Rehg. Cambridge: The MIT Press, 1998.

Habermas, J. "Plea for a constitutionalization of international law." Philosophy \& Social Criticism (2014), 40(1).

Habermas, J. The crisis of the European Union: a response. Translated from German by Ciaran Cronin. Cambridge: Polity Press, 2012.

HABERMAS, J. The theory of communicative action. Volume one: reason and the rationalization of society. Translated from German by Thomas McCarthy. Boston: Beacon Press, 1984.

HABERMAS, J. The theory of communicative action. Volume two: lifeworld and system. Translated from German by Thomas McCarthy. Boston: Beacon Press, 1987.

Transnationalizing the Public Sphere. Ed. Kate Nash. Cambridge: Polity Press, 2014.

Глобалізація в соціологічному вимірі. Під редакцією В. Степаненка та В. Бурлачука. Київ: Інститут соціології НАН України, 2011 [Hlobalizatsiia v sotsiolohichnomu vymiri. Pid redaktsiieiu V. Stepanenka ta V. Burlachuka. Kyiv: Instytut sotsiolohii NAN Ukrainy, 2011].

Козловски, П. Прощание с марксизмом-ленинизмом: о логике перехода от развитого социализма к этическому и демократическому капитализму. Очерки персоналистской философии. Перевод с немецкого, под редакцией М.Н. Грецкого. СПб: Экономическая школа, 1997 [Kozlovsкi, P. Proschanie s marksizmom-leninizmom: o logike perehoda ot razvitogo sotsializma $k$ eticheskomu i demokraticheskomu kapitalizmu. Ocherki personalistskoy filosofii. Perevod s nemetskogo, pod redaktsiey M.N. Gretskogo. SPb: Ekonomicheskaya shkola, 1997].

ХАБЕРМАС, Ю. Политические работы. Перевод с немецкого Б.М. Денежкина. Москва: Праксис, 2005 [Habermas, Yu. Politicheskie rabotyi. Perevod s nemetskogo B.M. Denezhkina. Moskva: Praksis, 2005].

\section{PROBLEM STATUSU GLOBALNEGO SPOŁECZEŃSTWA OBYWATELSKIEGO W OPRACOWANIACH NIEKTÓRYCH PRZEDSTAWICIELI EUROPEJSKIEJ TEORII KRYTYCZNEJ}

\section{STRESZCZENIE}

W artykule rozpatrzono problem określenia statusu globalnego społeczeństwa obywatelskiego, jak on został przedstawiony w opracowaniach odrębnych przedstawicieli europejskiej teorii krytycznej, między innymi w dziełach Nancy Fraser, Ulricha Becka oraz Jürgena Habermasa. Zostało szeroko zaprezentowane pojęcie narodowego społeczeństwa obywatelskiego i podano podstawowe elementy, niezbędne do jego tworzenia i funkcjonowania. Na podstawie dzieł wymienionych reprezentantów europejskiej teorii krytycznej zostało pokazane, że dla tego, aby mówić o pełnowartościowo rozbudowanym globalnym społeczeństwie obywatelskim, brakuje dotychczas niektórych podstawowych elementów. Określono sposoby rozwiązania problemu statusu globalnego społeczeństwa obywatelskiego, proponowane przez wymienionych wyżej przedstawicieli europejskiej teorii krytycznej.

Słowa kluczowe: globalne gospodarstwo kapitalistyczne; światowa wspólnota obywatelska; globalna sfera publiczna; nadnarodowa formacja państwowa; globalna myśl obywatelska. 